\title{
SERVICE GAP ANALYSIS IN RETAIL PETROLEUM INDUSTRY
}

\author{
Marie Wilson. $\mathrm{N}^{1}$, Thangavel. $\mathrm{N}^{2}$ \\ ${ }^{1}$ Director, ${ }^{2}$ Principal (Management Studies) \\ Jeppiaar Engineering College, Rajiv Gandhi Salai, Chennai - 119 \\ Email: thangavelraj@gmail.com
}

\begin{abstract}
In business and economics, gap analysis is a tool that helps a company to compare its actual performance with its potential performance. At its core are two questions: "Where are we?" and "Where do we want to be?" If a company or organization is not making the best use of its current resources or is forgoing investment in capital or technology, then it may be producing or performing at a level below its potential. This concept is similar to the base case of being below one's production possibilities frontier. The goal of gap analysis is to identify the gap between the optimized allocation and integration of the inputs, and the current level of allocation. This helps provide the company with insight into areas which could be improved. The gap analysis process involves determining, documenting and approving the variance between business requirements and current capabilities. Gap analysis naturally flows from benchmarking and other assessments. Once the general expectation of performance in the industry is understood, it is possible to compare that expectation with the company's current level of performance. This comparison becomes the gap analysis. Such analysis can be performed at the strategic or operational level of an organization. Hence, this study is undertaken to identify the service gap between the service providers and the customers in the petroleum retail outlets and to give suggestions to bridge the gap.
\end{abstract}

Key words: Gap Analysis, Fuel station, Petroleum Retailers, Retail Outlets, Supply Chain.

\section{INTRODUCTION}

Gap analysis provides a foundation for measuring investment of time, money and human resources required to achieve a particular outcome Note that 'GAP analysis' has also been used as a means for classification of how well a product or solution meets a targeted need or set of requirements. In this case, 'GAP' can be used as a ranking of 'Good', 'Average' or 'Poor'.

To identify a gap in the market, the technique of gap analysis can be used. Thus an examination of what profits are forecasted for the organization as a whole compared with where the organization (in particular its shareholders) 'wants' those profits to be represents what is called the 'planning gap': this shows what is needed of new activities in general and of new products in particular.

\section{SERVICES RENDERED}

Services offered are the most important and integral part of the retailing industry. In today's global environment, every organization is searching for innovative ways to achieve competitive advantage, increase customer loyalty, and improve efficiency without sacrificing quality of service. Confronted with these challenges, marketers are differentiating their product service offerings by cultivating long term relationships with their customers, who are setting new standards for service excellence.

\subsection{Additional Services Being Offered By Fuel Station}

The following are the services offered by the fuel stations or retail outlets

- Assured quality and quantity

- Efficient forecourt service like windshield cleaning, free air and water etc

- High levels of house keeping the RO clean and attractive user friendly

- Choice of regular and branded fuels

- $100 \%$ electronic dispensing

- Cashless transactions

- Loyalty programs for cash and credit customers

- Increased attention on the five point driveway service like pleasant manners, greeting customers, information on the products and fuels sold and maximizing the comfort of a customer at the retail outlet 
- Number of non-fuel offerings tailor made to customer profile and requirements like prepaid recharge cards

- Auto gas on alternative fuel is a good business proposition in the long term.

\section{RESEARCH GAP}

The origins of numerous instruments measuring service quality can perhaps be traced back the pioneering work by so many researchers. According to them, service quality is derived from a comparison between customer expectations and customer perceptions of actual service performance. The difference between perceptions and expectations results in the service quality gap. A wide gap would represent poor service quality and shows that the service provider needs to improve on the service offered to its customers. Further, in their study they also suggested that five dimensions namely, tangibles, reliability, assurance, responsiveness and empathy, influence service quality perceptions.

All the previous researches have been concentrated on the service quality gaps that exist in various other service sectors, based on the five dimensions advocated by experts. But the research for service gap in retail petroleum distribution is rare. Hence the researcher selects the topic "service gap analysis in retail petroleum distribution" for his study.

\section{OBJECTIVES OF THE STUDY}

- To identify the profile of the Petroleum Retailers and their organizational pattern, as the sample units selected for the study.

- To explore and analyze the relationship between customer expectation and strategies applied by retailers in this regard.

- To evaluate the relationship between the service design and standards selected by petroleum retailers.

- To examine the relationship between service standard delivery and matching performance of industries.

- To synthesize the impact of Gap analysis on customer satisfaction.

- To summarize the findings with legitimate measures and to extend valuable suggestion to minimize the service gap.

\section{RESEARCH DESIGN}

The study is convenient in nature as the researcher aims at analyze the service gap that exist in retail distribution, also analyze the reasons, lacking behind the better customers satisfaction that are being followed by retail distribution unit, the perception of customer about the service practices of the petroleum distribution concern and the impact towards the retailers. Based on the return of filled-in questionnaires, which were subsequently checked for completeness, 306 retail outlets and 594 customers were selected and taken into account for this research.

\section{ANALYSIS RELATED TO CUSTOMERS}

\subsection{Frequency of Educational Qualification}

Education is a powerful backgrounds for every individual that too for the customers to analysis the consequences of their consumption. It is found that most of the customers are having good educational background.

\section{Table 1 Educational Qualification of the respondents}

\begin{tabular}{|l|c|c|}
\hline \multicolumn{1}{|c|}{ Qualification } & Frequency & $\%$ \\
\hline Graduate & 178 & 30 \\
\hline Post graduate & 125 & 21 \\
\hline Professional & 119 & 20 \\
\hline Technical & 95 & 16 \\
\hline Others & 77 & 13 \\
\hline Total & 594 & 100 \\
\hline
\end{tabular}

It can be understood from the above table that the sample unit consists of $30 \%$ of customers with graduate qualification, followed by post graduates at $21 \%$, professional qualification $20 \%$, technical qualification at $16 \%$, and others at minimum level $(13 \%)$. The percentage analysis shows that the sample unit is dominated by the graduates.

\subsection{Frequency of different petroleum products needed by customers}

Every customer is interested to buy different fuel for their vehicle according to the quantity required. Here the percentage analysis is exploited to identify the consumer's need for different petroleum products. 
Table 2 Different petroleum products needed by customers

\begin{tabular}{|l|c|c|}
\hline Designation & Frequency & $\%$ \\
\hline Oil & 119 & 20 \\
\hline Diesel & 160 & 27 \\
\hline Petrol & 190 & 32 \\
\hline All & 125 & 21 \\
\hline Total & 594 & 100 \\
\hline
\end{tabular}

The above table reveals that the sample unit includes $32 \%$ of the respondents approach retailers for petrol, $27 \%$ of the respondent for diesel and $21 \%$ approach the retailers for oil, diesel and petrol products. But the responses for the oil are only at $20 \%$, the sample unit comprises of customers demanding petrol at highest level.

\subsection{Frequency of Retail Experience}

Consumer's experience with retail outlets of their need for petroleum products is very peculiar and continued relationships with the retailer help them to identify the quality service available in a particular retail outlet. Therefore it is analyzed as under.

Table 3. Frequency of Retail Experience

\begin{tabular}{|c|c|c|}
\hline Years & Frequency & Valid Percent \\
\hline Upto 10 & 101 & 17 \\
\hline $11-20$ & 184 & 31 \\
\hline $21-30$ & 190 & 32 \\
\hline Above 30 & 119 & 20 \\
\hline Total & 594 & 100 \\
\hline
\end{tabular}

The above table displays that $32 \%$ of customers are having $21-30$ years of experience, followed by $31 \%$ of the customers between 11 and 20 years of experience. The customers with above 20 years of experience are represented by $20 \%$, customers with upto 10 years of experience account for $17 \%$. It can be inferred that the sample unit consists of a maximum number of customers $63 \%$ with $10-20$ years of experience in. the field.

\subsection{Frequency of Income}

The income is the most important factor for all the customers to identify the reasons for their expectation and satisfaction, which will be useful for their economic augmentation

Table 4 Monthly income

\begin{tabular}{|c|c|c|}
\hline Monthly Income & Frequency & $\%$ \\
\hline$<$ Rs.50000 & 166 & 28 \\
\hline $50000-100000$ & 202 & 34 \\
\hline $100001-150000$ & 160 & 27 \\
\hline$>150000$ & 66 & 11 \\
\hline Total & 594 & 100 \\
\hline
\end{tabular}

The above table clearly indicates that the sample unit consists of $34 \%$ of customers earning a monthly income of Rs. 50000 - Rs. 100000 followed by $28 \%$ of customers at less than Rs50000 and $27 \%$ of customers earning a monthly income of Rs.1,00,001-Rs1, 50,000 and only $11 \%$ of the customers earning more than Rs.150000. It is also understood that the sample unit is more represented by an income group of Rs.50000-Rs. 150000 per month.

\section{ANALYSIS RELATED TO PETROLEUM RETAIL OUTLETS}

\subsection{Educational Qualification of the respondents}

Education is a powerful backgrounds for the retailers to analysis the consequences of service gap that exist in the retail outlet. It is found that most of the retailers are having good educational background.

Table 5 Education of the Retail

\begin{tabular}{|l|c|c|}
\hline \multicolumn{1}{|c|}{ Education } & Frequency & $\%$ \\
\hline Engineering & 92 & 30 \\
\hline Science graduates & 49 & 16 \\
\hline IT Graduates & 73 & 24 \\
\hline Post Graduate & 46 & 15 \\
\hline Degree with IT Diploma & 31 & 10 \\
\hline Others & 15 & 05 \\
\hline Total & 306 & 100 \\
\hline
\end{tabular}


It is found that 30 percent of the respondents are engineering graduates and $24 \%$ are IT Graduates, $16 \%$ are science graduates, $15 \%$ are postgraduates and $10 \%$ are degree holders with IT Diploma. It is also found that $5 \%$ have other educational backgrounds. It implies that in the sample study most of the retailers are engineering graduates.

\subsection{Nature of Ownership}

Since the retail outlets are recognized for its contribution of overall services to the end user, their services are inevitable for the economic development of the nation. The ownership pattern is also important to identify the administrative and organizational structure. The nature of ownership is analyzed here to get an effective impact on retail outlets.

Table 6 Nature of Ownership

\begin{tabular}{|l|c|c|}
\hline \multicolumn{1}{|c|}{ Option } & Frequency & $\%$ \\
\hline Sole proprietor & 254 & 83 \\
\hline Partnership & 40 & 13 \\
\hline Subsidiary & 12 & 4 \\
\hline Total & 306 & 100 \\
\hline
\end{tabular}

It is inferred that $83 \%$ of the respondents are sole Proprietors, $13 \%$ of the respondents are Partnership, and $4 \%$ of the respondents are Subsidiary. It is clear from the above analysis that most of the retail outlets are still under sole proprietorship.

\subsection{Annual Turnover of retail outlets}

Turnover is the only indicator of the firm's capacity and capability. Since turnover helps the firm to identify its performance and achievement, it is useful to have a successful planning. Here three different types of incomes are offered to the respondents. Its analysis is listed below

Table 7 Annual Turnover of retail outlets

\begin{tabular}{|c|c|c|}
\hline Annual Turnover in Rs. & Frequency & $\%$ \\
\hline Below 1 crore & 95 & 31 \\
\hline $1-5$ crores & 171 & 56 \\
\hline Above 5 crores & 40 & 13 \\
\hline Total & 306 & 100 \\
\hline
\end{tabular}

It is inferred that most of the retailers $(56 \%)$ are having $1-5$ crores turnover, followed by $31 \%$ at below one crore. But $13 \%$ of the respondents are having a highest turnover of more than 5 crores.

\subsection{Strength of Employees}

The success of every service sector depends upon the strength of the employees it posses and the sincere services offered to the customers. The retailers reply in this regard is analyzed as follows.

Table 8 Strength of Employees

\begin{tabular}{|c|c|c|}
\hline Strength of Employees & Frequency & $\%$ \\
\hline Below 5 & 46 & 15 \\
\hline $5-10$ & 119 & 39 \\
\hline Above 10 & 141 & 46 \\
\hline Total & 306 & 100 \\
\hline
\end{tabular}

It is inferred that $46 \%$ of the respondents are having a maximum strength of more than 10 employees, followed by $39 \%$ of the respondents are between $5-10$, and only $15 \%$ of the firm is having the minimum capacity of below 5 workers

\subsection{About customer service Policies in Practices}

There were some formal policies during pre and post independence period. After the introduction of Liberalization, Privatization, Globalization, most of the traditional firms are changing their structure and this envisages them to have a formal customer service policies. The following analysis picturise the respondents' opinions.

Table 9 About customer service Policies

\begin{tabular}{|c|c|c|}
\hline $\begin{array}{c}\text { About customer service } \\
\text { Policies }\end{array}$ & Frequency & $\%$ \\
\hline Yes & 278 & 91 \\
\hline No & 28 & 9 \\
\hline Total & 306 & 100 \\
\hline
\end{tabular}

From the above table it is inferred that $91 \%$ of the respondents agree that their units have a formal customer service policy, but only $9 \%$ of the respondents disagree with this statement.

\subsection{Supply chain Requirements}

In recent years, most of the petroleum retail outlets are converting their patterns according to the changes in the Global Economy. For all their changes, growth and development, they are in need of vendor 
support. Therefore the supply chain requirements is analyzed as follows,

Table 10 Supply chain Requirements

\begin{tabular}{|c|c|c|}
\hline Option & Frequency & $\%$ \\
\hline Yes & 287 & 94 \\
\hline No & 19 & 6 \\
\hline Total & 306 & 100 \\
\hline
\end{tabular}

From the above table it is inferred that, $94 \%$ of the respondents said that the unit requires a proper and regular support from the suppliers, on the other hand the disagreement to this statement is $6 \%$.

\section{MAJOR FINDINGS OF THE STUDY}

- It is identified that there exist the difference between the service expected by customers and the service they actually receive. If the customers are satisfied with the quality of the retailers then they are ready to wait and avail the services in that particular outlet.

- From the analysis it is identified that there is a difference between the quality level expected by customers and the perception of those expectations by the retailers because, the customers may place a greater emphasis on order accuracy than promptness of service.

- This is very clear from the analysis that some retail outlets do not have proper service design. Due to this there arises a gap between retailer's perception on customer expectations and the development of this perception into delivery standards.

- This is found out from the analysis that there is a gap between what is communicated to consumers and what is actually delivered. Some retail outlets are advertising, for instance, may indicate to consumers that they can have their car's oil changed within twenty minutes when, in reality, it takes more than thirty minutes.

- It is identified that the retail distributors after focus-group interviews are completed, they start measuring the expectations and experiences of the customers with more formal and quantitative methods.

- It is found out from the study that the gaps can be simply calculated as the arithmetic difference between the two measurements for each of the attributes. Retailer's perceptions are measured much in the same manner. After gaps are identified, retailers must take appropriate steps to fill or narrow the gaps.

- It is identified that customer satisfaction leads to repeat purchases and repeat purchases lead to loyal customers. In turn, customer loyalty leads to enhanced brand equity and higher profits. Consequently, understanding customer perceptions is important to a firm's performance. As such, gap analysis is used as a tool to narrow the gap between perceptions and reality, thus enhancing customer satisfaction.

- It is also identified that while service delivery can be changed through employee training, changes in product design are not as easily implemented and are more time consuming.

\section{MAJOR SUGGESTIONS}

- The service gap studies encompass the various developmental activities like performance assessment, potential appraisal, training and development required for service people, identifying the customers' expectations and planning for customer satisfaction.

- They should also incorporate the new mechanisms like customer relationship management, Petro card, fun at retail points, competency mapping and retention strategies. Petroleum Manufacturing Industries must try to follow the above strategies for the benefit of the retail outlets.

- The Executives of manufacturing industries, who are occupying a key role, should be educated to the Transformational Practices and equipping themselves for the present organizational environment. Therefore they can be able to monitor the supply side gap. They must be ready enough to imbibe the qualities to materialize the policy enforcement of the organizations.

- The learning programs offered to the employees of retail outlets are an indispensable tool to upgrade the employees. So, the industries may invest more funds on arranging the learning programs both theoretically and practically.

- The service gap in terms of customer relationship management develops core competencies, capabilities and capacities of the employees in the retail outlets. The strategies must be employed immediately in all the petroleum retailing 
organizations to improve the interpersonal relationship between customer and retailers to maintain competitiveness and capabilities.

- The business growth is not an independent phenomenon, but it depends upon proper analysis of customer's expectations and perfect evaluation of skills required to match the customer satisfaction. So, a flawless rigid system must be mechanized in every industry to monitor the growth of the retail distributions and customer's satisfaction simultaneously.

\section{CONCLUSION}

The research framework for this study is based on some important service gap practices as identified in various past researches namely, expectations of the customers, right services design and standards, and matching performance to promise, etc. Based on the result of the study, four important key elements are found to be correlated with the business performance with the exception for compensation/incentives and employees training. These results indicate that these factors will not likely to influence the overall business performance in the Indian petroleum manufacturing and distribution industries.

In conclusion, we can say all service gap analysis help to improve industries business performance including customer satisfaction, employee's productivity, product \& service quality and retailer's flexibility. From this result, it can be concluded that this study has achieved its main objective, which is to study about the effect of gap analysis towards the satisfaction of customer's of selected retailers of petroleum product distribution in Chennai .Furthermore, the analysis indicates that in general the gap analysis have some effect towards business performance, even though some of the factors of service gap did not show any support.

\section{BIBLIOGRAPHY}

\section{Books}

[1] Chunawalla, S.A, "Consumer Behaviour", Himalaya publishing house, second revised edition, 2005.

[2] Hill, W. L. C. \& Jones, R. G. (2007), Strategic Management: An Integrated Approach, 7th ed., Houghton Mifflin Company, Boston: New York.

[3] Kothari, C.R., "Research Methodology - Methods \& Technics", New Age International (P) limited, Publishers, New Delhi, second reprint edition, 2004.
[4] Lynch, R. (2003), Corporate Strategy, 3rd ed., Prentice Hall Financial Times.

[5] Plenert, Gerhard. The Manager: Value Chain Management in an e-Commerce World. Dublin, Ireland: Blackhall Publishing, 2001.

[6] Raju, M.S \& Dominique Xardel,"Consumer behaviour Concepts, Applications and Cases", Vikas Publishing House Private Limited, New Delhi, Second reprint, 2005.

[7] Ravilochanan, P.Dr., "Research Methodology". Margham Publications,Chennai-17, $2^{\text {nd }}$ Edition, 2003.

\section{Journals and Research Papers}

[1] Ghamdi, S. M. Al (2005), The Use of Strategic Planning Tools and Techniques in Saudi Arabia: An Empirical study, International Journal of Management, Vol. 22, No. 3, p. 376-395.

[2] Gottfredson, M. \& Puryear, R. \& Phillips, S. (2005), Strategic Sourcing From Periphery to the Core, Harvard Business Review, Vol. 83, No. 2, p. 132-139.

[3] International Operations Management. Copenhagen, Denmark: Copenhagen Business School Press, 2002.

[4] Macmillan, H. \& Tampoe, M. (2000), Strategic Management, Oxford University Press.

[5] Magretta, J. (2002), Why business models matter, Harvard Business Review.

[6] Moore, G. A. (2005), Strategy and your stronger hand, Harvard Business Review.

[7] Pathania-Jain, G. (2001), Global parents, local partners: A value-chain analysis of collaborative strategies of media firms in India, Journal of Media Economics, Vol. 14, No. 3, p. 169-187.

[8] Rai, S. (2006), India becoming a crucial cog in the machine at IBM, The New York Times.

[9] Rainbird, M. (2004), A framework for operations management: the value chain, International Journal of Physical Distribution \& Logistics Management, Vol. 34, No. $3 / 4$.

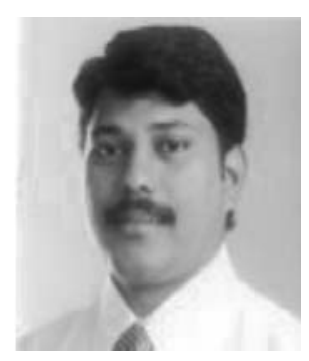

Er. N. Marie Wilson is the Director of Jeppiaar Engineering College, Chennai-119. He has coordinated various Sports activities and Industry and Institute interactions. He has published 5 papers in International and 3 papers in National Journals and presented 10 papers in both International and National conferences. He is specialized in Marketing, Human Resource and Computer Science and he has more focus on Research and Development. 